THE FIRE 


\section{THE FIRE}

\section{Collected Essays of Robin Blaser}

Edited and with a commentary

by Miriam Nichols

무

University of California Press

Berkeley Los Angeles London 
University of California Press, one of the most distinguished university presses in the United States, enriches lives around the world by advancing scholarship in the humanities, social sciences, and natural sciences. Its activities are supported by the UC Press Foundation and by philanthropic contributions from individuals and institutions. For more information, visit www.ucpress.edu.

For acknowledgments of permissions, please see page $48 \mathrm{I}$. The photograph used as a frontispiece is reproduced courtesy of Christos Dikeakos. Photographs that appear in the illustration section (following page $4 \mathrm{r}$ o), except for the last one, are reproduced courtesy of Robin Blaser.

University of California Press

Berkeley and Los Angeles, California

University of California Press, Ltd.

London, England

C 2006 by The Regents of the University of California

Library of Congress Cataloging-in-Publication Data

Blaser, Robin.

The fire : collected essays of Robin Blaser / Robin Blaser ; edited and with a commentary by Miriam Nichols.

$$
\text { p. } \mathrm{cm} \text {. }
$$

Includes bibliographical references and index.

ISBN-I 3 978-0-520-245 I0-5 (alk. paper), ISBN-I 0 0-5 20-245 I 0-5 (alk. paper) - ISBN-I 3 978-0-520245 II-2 (pbk. : alk. paper), ISBN-I ० 0-520-245 II-3 (pbk. : alk. paper)

I. Poetics. 2. Poetry-History and criticism. I. Nichols, Miriam. II. Title.

PS 355 2.L37F57 2006

808. I- dc 22 2005025772

Manufactured in the United States of America
$\begin{array}{llllllllll}\text { I } 5 & \text { I } 4 & \text { I 3 } & \text { I } 2 & \text { II } & \text { IO } & 09 & 08 & 07 & 06\end{array}$

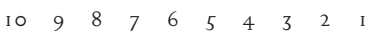

This book is printed on New Leaf EcoBook 50, a $100 \%$ recycled fiber of which $50 \%$ is de-inked post-consumer waste, processed chlorine-free. EcoBook 50 is acid-free and meets the minimum requirements of ANSI/ASTM D5634-O I (Permanence of Paper). 
nothing simpler than what I have said because I didn't say it, nothing simpler than what

I have said, because I said it-

Robin Blaser, "The Art of Combinations,"

The Holy Forest 
